Acta vet. scand. $1987,28,33-45$.

From the Division of Parasitology, Department of Internal Medicine I, Norwegian College of Veterinary Medicine, Oslo, Norway.

\title{
Effects of Leucocyte Extract, Levamisole and Sulphadimidine on Natural Coccidial Infections (Eimeria Spp.) in Young Lambs
}

\author{
By Bjørn Gjerde and Oddvar Helle
}

\begin{abstract}
Gjerde, B. and O. Helle: Effects of leucocyte extract, levamisole and sulphadimidine on natural coccidial infections (Eimeria spp.) in young lambs. Acta vet. scand. 1987, 28, 33-45. - The efficacy of leucocyte extract (LE) and sulphadimidine in preventing coccidiosis in naturally infected lambs on pasture was evaluated in 3 separate experiments, whereas the prophylactic effect of levamisole was studied in 1 of the experiments. LE prepared from ewes immune to coccidia (Eimeria spp.) was administered either intravenously or intraperitoneally to young lambs 7,5 , or 2 days before they were turned out on pastures contaminated with coccidia. In all experiments, LE failed to transfer protective immunity to the lambs against the first coccidial infection on pasture. The LE preparations used apparently had an immunosuppressive effect, which resulted in more severe clinical signs of coccidiosis in the recipients. The lambs given LE showed a higher incidence of diarrhoea, a poorer weight gain, a higher mortality, and a higher oocyst output than the untreated control lambs. In lambs treated with sulphadimidine at $200 \mathrm{mg} / \mathrm{kg}$ on days 12,13 , and 14 after turnout there was a reduced severity of the coccidial infections in all experiments. The sulphadimidine-treated lambs had better weight gains and passed fewer oocysts than the controls during the third and fourth week after turnout, but some of them developed diarrhoea. Lambs treated with levamisole at $2 \mathrm{mg} / \mathrm{kg} 2$ days before turnout, at turnout, and 2 days after turnout were more severely affected by the first coccidial infection on pasture than the controls.

To study the lambs' immunity against a heavy challenge infection with coccidia as compared with their immunity against the natural reinfection on pasture, some of the lambs from the original groups (untreated, sulphadimidine-treated, LE-treated) were each inoculated with 2 mill. Eimeria spp. oocysts about 6 weeks after turnout. The oocyst counts of the challenged lambs, except the LE-treated lambs, increased to a new peak 19-20 days after challenge. The challenge infection caused a softening of the faeces and a marked depression in weight gain in all challenged groups of lambs, mainly between days 10 and 17 after challenge. The lambs were thus only partially immune to coccidia after the first coccidial infection on pasturé. The lambs treated with either LE or sulphadimidine in connection with the first coccidial infection on pasture were not appreciably more susceptible to the challenge infection than the untreated lambs.
\end{abstract}

sheep; transfer factor; immunity. 


\section{Introduction}

In Norway, coccidiosis due to infections with Eimeria spp. is an important disease in young lambs on pasture. Most lambs spend their first weeks of life indoors, and in this period they have very little exposure to infective oocysts and little or no immunity to coccidia is acquired. When the lambs are put out on pastures grazed by sheep in the previous grazing seasons, they rapidly become infected with overwintered oocysts, mainly as a result of their habit of eating soil (Helle 1970, Helle \& Hilali 1973). The ingestion of owerwintered oocysts by virtually nonimmune lambs during their first day(s) on pasture, frequently results in clinical coccidiosis 2-3 weeks later. Clinical signs include diarrhoea, dehydration, anorexia, loss of weight, and some lambs may die. The immunity induced by the first infection seems to protect most lambs from the reinfections with coccidia later in the grazing season. Thus, if the lambs had been partially immune to coccidia when turned out on contaminated pastures, severe outbreaks of coccidiosis would probably not have occurred.

Cell-mediated immune responses have been found to play the major role in hostprotective immunity to coccidia (Rose 1982). Cell-mediated immune reactivity (e.g. cutaneous delayed-type hypersensitivity) may be transferred from sensitive donors to insensitive, genetically unrelated recipients by using cell-free extracts or lysates of leucocytes from immune donors (Lawrence 1955). The material responsible for this transfer is also present in the dialysate after dialysis of the cell lysates, and has been designated dialyzable transfer factor. Transfer factor has been defined as the material in leucocyte lysates that is responsible for the transfer of antigen-specific cell-mediated reactivity, whereas several other small, pharmacologically active molecules in such leucocyte lysates (histamine, serotonin, bradykinin, ascorbate, nicotinamide, prostaglandins, thymosine) may have nonspecific stimulating or suppressive effects on immune or inflammatory responses (Klesius et al. 1980, Lawrence \& Borkowsky 1983).

Liburd et al. (1972) reported that cell lysates from rats immune to the coccidian parasite Eimeria nieschulzi conferred partial immunity against infection with this parasite to previously nonimmune recipient rats. Likewise, it was found that "transfer factor" from bovines immunized against Eimeria bovis was able to transfer partial immunity to infection with E. bovis in calves, and to infections with Eimeria ferrisi in mice (Klesius et al. 1975, Klesius \& Kristensen 1977, Klesius et al. 1978, Klesius et al. 1979). When compared with the untreated controls, the animals treated with these cell extracts showed less severe clinical symptoms and a reduced oocyst output. In sheep, partial protection against infections with the nematodes Trichostrongylus axei, Trichostrongylus colubriformis and Ostertagia circumcincta, and Haemonchus contortus was transferred to nonimmune recipients with leucocyte lysates from donors immunized against these parasites (Ross \& Halliday 1979a, Ross \& Halliday 1979b, Ross et al. 1979). These reports were encouraging and suggested that it might be possible to transfer partial immunity to coccidia to nonimmune lambs using leucocyte lysates prepared from immune donor sheep.

The anthelmintic drug levamisole is capable of potentiating immunity by enhancing cellmediated immune responses when used at dosages of $2-3 \mathrm{mg} / \mathrm{kg}$ body weight. The drug has an immunopotentiating effect mainly in animals with a defective cellmediated immune function (Brunner \& Muscoplat 1980). Hence, it was possible that levamisole treatment at turnout would sti- 
mulate the development of immunity in the lambs, and make them less susceptible to the first coccidial infection on pasture.

The present paper describes 3 separate experiments in which lambs were treated with leucocyte extract (LE) from coccidia-immune donors prior to turnout in an attempt to give them a protective level of immunity against the initial coccidial infection on pasture. The effect of this type of prophylaxis against coccidiosis was compared with the effect of preventive medication with sulphadimidine. Moreover, in one experiment lambs were treated with levamisole at turnout in an attempt to potentiate their development of immunity to coccidia.

\section{Materials and methods}

\section{Experimental animals}

Fifty-one lambs were used in Experiment 1 in 1981, 36 lambs were used in Experiment 2 in 1982, and 48 lambs were used in Experiment 3 in 1983. The lambs (mostly twins) were either of the Dala breed, or were Dala $\times$ Rygja crossbreds. They were kept together with their parent ewes throughout the experiments. The lambs were kept indoors in pens with slatted floors from their birth until they were turned out on pasture in mid-May. At turnout (on day 0), the lambs were from 11 to 49 days old; most of them being from 3 to 4 weeks old. They were randomly assigned to experimental groups.

\section{Coccidial infections}

In all experiments the lambs were turned out on a permanent sheep pasture (at Kjeller Research Farm), and acquired a natural infection with coccidia. In each of Experiments 2 and 3, 12 lambs were experimentally reinfected with sporulated Eimeria spp. oocysts about 6 weeks after turnout, in order to study their immunity to a heavy challenge infection shortly after the initial infection on pasture. The oocysts used for this inoculation were isolated from the faeces of lambs with high oocyst counts due to the initial coccidial infection. The oocysts were sporulated in a potassium bichromate solution, concentrated by sugar flotation, washed in water by repeated centrifugation, and stored in a refrigerator at $4^{\circ} \mathrm{C}$ until used. Each lamb was given about 2 mill. Eimeria spp. oocysts by stomach tube.

\section{Preparation of leucocyte extract}

The cell extracts used in the experiments were prepared from peripheral blood leucocytes, spleen cells, and mesenteric lymph node cells from 2 ewes (6.5 and 3.5 years old). Both donor ewes were assumed to have a solid immunity to Eimeria spp. as a result of previous repeated exposure to oocysts, mainly on pasture. In addition, each ewe was inoculated with about 2 mill. sporulated Eimeria spp. oocysts, and 29 days after this challenge infection, $270 \mathrm{ml}$ of venous blood was collected from each ewe. Heparin at a final concentration of $10 \mathrm{iu} / \mathrm{ml}$ served as anticoagulant. Three days later both ewes were killed (in October 1980) and their spleens and mesenteric lymph nodes were collected. One volume of heparinized venous blood was mixed with 5 volumes of ammoniumchloride/Tris at $37^{\circ} \mathrm{C}$ for lysis of red blood cells. After $3 \mathrm{~min}, 5$ volumes of phosphate buffered saline (PBS) were added, the cells were spun down and washed once in PBS. The cells were resuspended in $0.9 \% \mathrm{NaCl}$, counted and frozen at $-70^{\circ} \mathrm{C}$.

Mesenteric lymph nodes and spleens (each type of tissue from each animal being treated separately) were minced and pressed through sieves into flasks containing Hanks' balanced salt solution (HBSS). The resulting material was filtered through gauze to remove coarse particles and the cells were pel- 
leted by centrifugation. The cells were washed once in HBSS, resuspended in the same medium for counting, and frozen at $-70^{\circ} \mathrm{C}$. The cell suspensions were alternately frozen $\left(-70^{\circ} \mathrm{C}\right)$ and thawed $\left(5^{\circ} \mathrm{C}\right) 10$ times to lyse the cells. Cellular debris was removed from the cell lysate by centrifugation at $40,000 \mathrm{~g}$ for $45 \mathrm{~min}$. The resulting suspensions were diluted with $0.9 \% \mathrm{NaCl}$ and filtered through a PM-10 Amicon filter (excluding material with a molecular weight $>10,000$ daltons) in a sterilized Amicon Standard 52 Cell. The ultrafiltrated extracts of peripheral blood leucocytes, spleen cells, and lymph node cells, respectively, from both ewes were pooled and stored at $-20^{\circ} \mathrm{C}$ until used (6 to 30 months later). The different types of cell extract will all be referred to as leucocyte extract (LE) in the following.

\section{Experimental design}

Experiment 1. The experiment comprised 3 groups. The 12 lambs in group 1 were untreated controls, whereas each of the 13 lambs in group 2 was given sulphadimidine per os (a $16.7 \%$ aqueous solution of sulphadimidine sodium prepared by mixing equal volumes of Rigesol $^{R}$ and water) at a dose rate of $200 \mathrm{mg} / \mathrm{kg}$ on days 12,13 , and 14 after turnout. The 26 lambs in group 3 each received $1.8 \mathrm{ml}$ of leucocyte extract, containing $1.8 \times 10^{9}$ cell equivalents, intraperitoneally 5 days before turnout. Thirteen lambs were given spleen-derived leucocyte extract and 13 lambs were given lymph nodederived extract.

Faecal samples were collected from the lambs 1 day before turnout and on days 7, $14,17,21,24$, and 28 after turnout. The lambs were weighed (to the nearest $0.1 \mathrm{~kg}$ ) 1 day before turnout and on days 7, 14, 21, 28 , and 35 after turnout.

Experiment 2. The first part of the experiment comprised 3 groups consisting initially of 12 lambs each. The lambs in group 1 were untreated controls, those in group 2 were treated with sulphadimidine as in Experiment 1 , while the lambs in group 3 each received $1.8 \mathrm{ml}$ of leucocyte extract (derived from lymph node or spleen cells), containing $1.8 \times 10^{9}$ cell equivalents, intravenously 7 days before turnout.

Faecal samples were collected from the lambs 1 day before turnout and on days 7 , $14,16,19,21$, and 28 after turnout. The lambs were weighed 1 day before turnout and on days $7,14,21$, and 28 after turnout. The second part of the experiment comprised 24 lambs, with 8 lambs from each of the 3 original groups. Each original group was divided into 2 subgroups (A and B), comprising 4 lambs each. The 4 lambs in each of group 1B, 2B, and $3 \mathrm{~B}$ were each orally inoculated with about 2 mill. sporulated Eimeria spp. oocysts on day 42 after turnout. The remaining 12 lambs (group 1A, $2 \mathrm{~A}$, and $3 \mathrm{~A}$ ) were only exposed to the natural reinfection on pasture. The lambs in group $3 \mathrm{~A}$ and $3 \mathrm{~B}$ were each given $1 \mathrm{ml}$ of leucocyte extract, containing $1 \times 10^{9}$ cell equivalents, intravenously 7 days before the experimental reinfection with coccidia.

Faecal samples were collected on the inoculation day and on days $7,14,16,19,21$, and 28 after inoculation. The lambs were weighed on the inoculation day and on days 7, 14, 21 , and 28 after inoculation.

Experiment 3 . The first part of the experiment comprised 4 groups consisting initially of 12 lambs each. The lambs in group 1 were untreated controls, those in group 2 were treated with sulphadimidine as in Experiment 1 , and those in group 3 each received $2 \mathrm{ml}$ of leucocyte extract (derived from peripheral blood leucocytes), containing about $2 \times 10^{8}$ cell equivalents, intraperitoneally 2 days before turnout. Finally, the lambs in group 4 each received levamisole 
hydrochloride (Levoripercol ${ }^{\mathrm{R}}$ ) subcutaneously at a dose rate of $2 \mathrm{mg} / \mathrm{kg}$ on day 2 before turnout, a few hours before turnout, and on day 2 after turnout.

Faecal samples were collected on days 6, 14, 21,28 , and 35 after turnout, and the lambs were weighed on day 2 before turnout and on days $6,14,21,28$, and 35 after turnout.

The second part of the experiment comprised 8 lambs from each of groups 1, 2 and 3, i.e. a total of 24 lambs. Four lambs from each of the 3 original groups were each orally inoculated with about 2 mill. oocysts on day 44 after turnout (groups 1B, 2B, 3B). The remaining 12 lambs served as naturally reinfected controls (group 1A, 2A, 3A).

Faecal samples were collected, and the lambs were weighed 2 days before the experimental reinfection, and on days 11, 20, 27 and 39 after inoculation. In addition, the weight was recorded on days 14 and 17 after inoculation.

\section{Faecal examinations}

Faecal samples were collected and examined as described previously (Gjerde \& Helle 1986). Briefly, each faecal sample was given a faecal consistency score (FCS) after the following criteria: 1 = normal pelleted faeces; 2 = soft pelleted faeces; 3 = pastelike faeces; 4 $=$ liquid faeces (diarrhoea). Because faecal samples rarely were obtained from all lambs in a given group on a given sampling day, the frequencies of diarrhoea referred to later, which were based on the faecal samples, may not correspond entirely to the actual frequencies of diarrhoea in the different groups. The number of oocysts per gram of faeces was determined after a modified McMaster technique.

\section{Post mortem examinations}

Lambs that died (or were killed after they had become moribund) were necropsied at the Department of Pathology. A positive diagnosis of coccidiosis was based mainly on the presence of large numbers of oocysts in smears of the intestinal contents, and/or on the presence of large numbers of developmental stages of coccidia in histological sections of the intestinal mucosa.

\section{Statistical evaluations}

Analysis of variance was used to test for significant differences between the groups with respect to daily weight gains, faecal consistency scores and oocyst counts as described previously (Gjerde \& Helle 1986).

\section{Results}

\section{Experiment 1}

Three lambs in group 3 (LE-treated) died of coccidiosis on days 18,19 , and 19 , respectively, after turnout on pasture, whereas no lambs in the 2 other groups died.

The mean oocyst counts of the 3 groups between days 14 and 28 after turnout are shown in Table 1. The treatment with sulphadimidine reduced the oocyst output, in part significantly, whereas the treatment with LE increased the oocyst output.

The mean FCSs of the 3 groups from day 14 to day 28 are shown in Table 2. Group 3 lambs had the highest, and group 2 lambs the lowest, mean FCSs from day 17 onwards. The frequencies of faecal samples with a liquid (diarrhoeic) consistency on days 17,21 , and 24 were $14 \%$ in group 1 , $8 \%$ in group 2 , and $41 \%$ in group 3, whereas $31 \%, 23 \%$ and $28 \%$ of the samples collected on the same 3 days from groups 1,2 and 3 , respectively, had a pastelike consistency. 
Table 1. Mean number of oocysts/g faeces $\left(\times 10^{-3}\right)$ on specified days (D) after turnout on day 0 in Experiment 1 .

\begin{tabular}{llrrrrr}
\hline Group & Treatment & D 14 & D 17 & D 21 & D 24 & D 28 \\
\hline 1 & No treatment & $936.0^{\mathrm{a}}$ & $320.4^{\mathrm{a}}$ & $605.5^{\mathrm{a}}$ & $399.8^{\mathrm{ab}}$ & $544.6^{\mathrm{a}}$ \\
2 & Sulphadimidine $^{1}$ & $423.9^{\mathrm{a}}$ & $2.4^{\mathrm{b}}$ & $178.8^{\mathrm{b}}$ & $268.5^{\mathrm{b}}$ & $300.5^{\mathrm{b}}$ \\
3 & LE $^{2}$ & $287.5^{\mathrm{a}}$ & $531.6^{\mathrm{a}}$ & $1055.0^{\mathrm{a}}$ & $544.6^{\mathrm{a}}$ & $419.4^{\mathrm{ab}}$ \\
\hline
\end{tabular}

${ }^{1}$ : Sulphadimidine at a dose rate of $200 \mathrm{mg} / \mathrm{kg}$ per os on days 12,13 and 14 after turnout.

${ }^{2}$ : Leucocyte extract at a dose rate of $1.8 \times 10^{9}$ leucocyte equivalents i.p. on day 5 before turnout.

a, b, c: Within each column, means with the same superscript are not significantly different $(P<0.05)$.

Group 2 had the best, and group 3 the poorest, weight gain during the third and fourth week after turnout (Table 2), but the weight gains of neither of these groups differed significantly from those of the control group.

\section{Experiment 2}

Initial infection. Two control lambs died on days 20 and 22 respectively, after turnout, 1 sulphadimidine-treated lamb died on day 21, while 2 LE-treated lambs died on days 18 and 21 respectively, after turnout. All deaths were due to coccidiosis.

Table 3 shows the mean oocyst counts of the 3 groups between days 14 and 28 . Treatment with sulphadimidine markedly reduced the oocyst output. Thus, group 2 had significantly lower mean oocyst counts than the 2 other groups between days 14 and 21 .
The mean FCSs between days 14 and 28 are shown in Table 4. The FCS of Group 3 (LE-treated) was significantly higher than those of groups 1 and 2 both on day 19 and when the data from all sampling days between days 14 and 21 were pooled. The frequencies of faecal samples with a diarrhoeic consistency on days $14,16,19$, and 21 were $22 \%$ in group 1, $23 \%$ in group 2, and $44 \%$ in group 3, whereas $29 \%, 28 \%$, and $40 \%$ of the samples collected on the same 4 days from groups 1, 2, and 3, respectively, had a pastelike consistency.

Group 2 had the best weight gain during the experiment. Group 3 had a significantly lower mean daily weight gain than the other groups between days 14 and 21 , and between days 14 and 28 (Table 4).

Reinfection. Faecal oocyst numbers were still fairly high in all groups at the time of

Table 2. Mean faecal consistency score ${ }^{1}$ and daily weight gain (in grams) on specified days (D) or in specified time periods after turnout on pasture on day 0 in Experiment 1.

\begin{tabular}{|c|c|c|c|c|c|c|c|}
\hline \multirow[t]{2}{*}{ Group ${ }^{2}$} & \multicolumn{5}{|c|}{ Faecal concistency score } & \multicolumn{2}{|c|}{ Weight gain } \\
\hline & D 14 & D 17 & D 21 & D 24 & $14-28$ & $14-21$ & $14-28$ \\
\hline 1 & $1.45^{\mathrm{a}}$ & $2.42^{b}$ & $2.83^{\mathrm{ab}}$ & $2.08^{\mathrm{a}}$ & $2.16^{\mathrm{a}}$ & $127^{\mathrm{ab}}$ & $204^{\mathrm{ab}}$ \\
\hline 2 & $1.46^{\mathrm{a}}$ & $2.08^{b}$ & $2.23^{b}$ & $1.62^{\mathrm{a}}$ & $1.71^{b}$ & $236^{\mathrm{a}}$ & $269^{a}$ \\
\hline 3 & $1.92^{\mathrm{a}}$ & $3.24^{\mathrm{a}}$ & $3.33^{\mathrm{a}}$ & $2.26^{\mathrm{a}}$ & $2.46^{\mathrm{a}}$ & $27^{\mathrm{b}}$ & $139^{\mathrm{b}}$ \\
\hline
\end{tabular}

1: See Materials and methods.

2: For treatments, see Table 1.

a, b, c: Within each column, means with the same superscript are not significantly different $(\mathrm{P}<0.05)$. 
Table 3. Mean number of oocysts/g faeces $\left(\times 10^{-3}\right)$ on specified days (D) after turnout on day 0 in Experiment 2.

\begin{tabular}{|c|c|c|c|c|c|c|}
\hline Group & Treatment & D 14 & D 16 & D 19 & D 21 & D 28 \\
\hline 1 & No treatment & $617.4^{a}$ & $332.9^{\mathrm{a}}$ & $1428.7^{\mathrm{a}}$ & $738.1^{\mathrm{a}}$ & $439.5^{\mathrm{a}}$ \\
\hline 2 & Sulphadimidine $^{1}$ & $48.8^{b}$ & $8.8^{\mathrm{b}}$ & $95.9^{\mathrm{b}}$ & $182.9^{\mathrm{b}}$ & $474.6^{\mathrm{a}}$ \\
\hline 3 & $\mathrm{LE}^{2}$ & $534.1^{\mathrm{a}}$ & $659.3^{\mathrm{a}}$ & $2271.0^{\mathrm{a}}$ & $1749.1^{\mathrm{a}}$ & $1260.7^{\mathrm{a}}$ \\
\hline
\end{tabular}

1: Sulphadimidine at a dose rate of $200 \mathrm{mg} / \mathrm{kg}$ per os on days 12,13 and 14 after turnout.

2: Leucocyte extract at a dose rate of $1.8 \times 10^{9}$ leucocyte equivalents i.v. on day 7 before turnout.

a, b, c: Within each column, means with the same superscript are not significantly different $(P<0.05)$.

challenge on day 42 after turnout, but oocyst numbers declined in all groups during the first 2 weeks after challenge. The oocyst numbers then increased to a new peak in the challenged groups 1B (untreated) and 2B (sulphadimidine-treated) on day 19 after challenge. In the challenged group 3B (LEtreated), and in all unchallenged groups, the oocyst numbers either showed a further decline or remained at a constant, low level during weeks 3 and 4 after challenge. On day 19 after challenge, the different groups had the following mean oocyst counts: (1A) 90 700; (1B) 405 600; (2A) 68 000; (2B) 615 500; (3A) 39 400; (3B) 51 200. There were no significant differences in oocyst counts between any groups on any sampling day.

Some challenged lambs, especially in groups $2 \mathrm{~B}$ and $3 \mathrm{~B}$, showed a softening of their faeces during the third week after challenge, but none of them developed diarrhoea.

The challenged groups had a markedly poorer weight gain than the unchallenged groups between days 7 and 14 after challenge. Thus, the mean daily weight gains of groups $1 \mathrm{~A}, 2 \mathrm{~A}$, and $3 \mathrm{~A}$ were respectively 286, 261, and 321 grams, whereas the weight gains of groups $1 \mathrm{~B}, 2 \mathrm{~B}$, and $3 \mathrm{~B}$ were 86,11 , and 11 grams, respectively. Groups 2B and $3 \mathrm{~B}$ had a significantly lower weight gain than the corresponding unchallenged groups (2A and $3 \mathrm{~A}$ ) in this period. In weeks 3 and 4 after challenge the daily weight gains of the challenged groups were similar to those of the unchallenged groups, but the inoculated lambs were not able to compensate for the previous depression in weight gain during the last 2 weeks of observation.

Table 4. Mean faecal consistency score ${ }^{1}$ and daily weight gain (in grams) on specified days (D) or in specified time periods after turnout on pasture on day 0 in Experiment 2.

\begin{tabular}{|c|c|c|c|c|c|c|c|}
\hline \multirow[t]{2}{*}{ Group $^{2}$} & \multicolumn{5}{|c|}{ Faecal concistency score } & \multicolumn{2}{|c|}{ Weight gain } \\
\hline & D 14 & D 16 & D 19 & D 21 & D 28 & $14-21$ & $14-28$ \\
\hline 1 & $1.67^{\mathrm{b}}$ & $2.60^{\mathrm{a}}$ & $2.73^{b}$ & $2.64^{\mathrm{ab}}$ & $1.10^{\mathrm{a}}$ & $81^{\mathrm{a}}$ & $176^{\mathrm{a}}$ \\
\hline 2 & $2.42^{\mathrm{ab}}$ & $2.20^{\mathrm{a}}$ & $2.56^{\mathrm{b}}$ & $2.00^{\mathrm{b}}$ & $1.13^{\mathrm{a}}$ & $204^{a}$ & $218^{\mathrm{a}}$ \\
\hline 3 & $2.92^{\mathrm{a}}$ & $3.17^{\mathrm{a}}$ & $3.78^{\mathrm{a}}$ & $3.22^{\mathrm{a}}$ & $1.20^{\mathrm{a}}$ & $-100^{b}$ & $54^{b}$ \\
\hline
\end{tabular}

1: See Materials and methods.

2: For treatments, see Table 3.

a, b, c: Within each column, means with the same superscript are not significantly different $(P<0.05)$. 
Table 5. Mean number of oocysts/g faeces $\left(\times 10^{-3}\right)$ on specified days (D) after turnout on day 0 in Experiment 3.

\begin{tabular}{llrrrr}
\hline Group & Treatment & D 14 & D 21 & D 28 & D 35 \\
\hline 1 & No treatment & $45.2^{\mathrm{b}}$ & $3359.4^{\mathrm{a}}$ & $405.3^{\mathrm{a}}$ & $580.3^{\mathrm{a}}$ \\
2 & Sulphadimidine $^{1}$ & $13.8^{\mathrm{c}}$ & $282.8^{\mathrm{b}}$ & $183.3^{\mathrm{a}}$ & $205.5^{\mathrm{b}}$ \\
3 & LE $^{2}$ & $365.1^{\mathrm{a}}$ & $1243.2^{\mathrm{a}}$ & $902.9^{\mathrm{a}}$ & $937.0^{\mathrm{a}}$ \\
4 & Levamisole $^{3}$ & $543.4^{\mathrm{a}}$ & $1993.7^{\mathrm{a}}$ & $505.1^{\mathrm{a}}$ & $628.3^{\mathrm{ab}}$ \\
\hline
\end{tabular}

${ }^{1}$ : Sulphadimidine at a dose rate of $200 \mathrm{mg} / \mathrm{kg}$ per os on days 12,13 and 14 after turnout.

2: Leucocyte extract at a dose rate of $2 \times 10^{8}$ leucocyte equivalents i.p. on day 2 before turnout.

3: Levamisole at a dose rate of $2 \mathrm{mg} / \mathrm{kg}$ s.c. on day 2 before turnout, at turnout, and on day 2 after turnout.

a, b, c: Within each column, means with the same superscript are not significantly different $(P<0.05)$.

\section{Experiment 3}

Initial infection. One sulphadimidinetreated lamb (group 2) died on day 19 after turnout, while 3 levamisole-treated lambs (group 4) died on days 19, 21, and 28, respectively, after turnout. The necropsy showed that these lambs died of coccidiosis. In addition, one lamb in group 4 died from volvulus on day 9 after turnout.

Table 5 shows the mean oocyst counts of the 4 groups between days 14 and 35 . There was unfortunately no faecal sampling between day 14 and day 21 in this experiment. On days 14 and 21 , the oocyst counts of group 2 were significantly lower than those of the other groups.
There were no significant differences between the groups on any single day with respect to mean FCS (Table 6). However, when the data from days 14,21 , and 28 were pooled, the FCS of group 4 was significantly higher than that of the control group. On day 21 after turnout, 22, 22, 45, and 33 per cent of the faecal samples from groups $1,2,3$, and 4 , respectively, had a diarrhoeic consistency.

Group 2 had the highest mean daily weight gain during the experiment. In the period between days 14 and 21 after turnout, group 2 had a significantly better weight gain than groups 3 and 4 (Table 6).

Table 6. Mean faecal consistency score ${ }^{1}$ and daily weight gain (in grams) on specified days (D) or in specified time periods after turnout on pasture on day 0 in Experiment 3.

\begin{tabular}{|c|c|c|c|c|c|c|}
\hline \multirow[t]{2}{*}{ Group ${ }^{2}$} & \multicolumn{4}{|c|}{ Faecal concistency score } & \multicolumn{2}{|c|}{ Weight gain } \\
\hline & D 14 & D 21 & D 28 & $14-28$ & $14-21$ & $14-28$ \\
\hline 1 & $1.00^{\mathrm{a}}$ & $2.22^{\mathrm{a}}$ & $1.20^{\mathrm{a}}$ & $1.42^{\mathrm{b}}$ & $112^{\mathrm{ab}}$ & $214^{\mathrm{ab}}$ \\
\hline 2 & $1.36^{\mathrm{a}}$ & $1.78^{\mathrm{a}}$ & $1.44^{\mathrm{a}}$ & $1.52^{\mathrm{a}}$ & $239^{a}$ & $248^{\mathrm{a}}$ \\
\hline 3 & $1.45^{\mathrm{a}}$ & $2.91^{\mathrm{a}}$ & $1.58^{\mathrm{a}}$ & $1.97^{\mathrm{ab}}$ & $18^{\mathrm{b}}$ & $116^{\mathrm{b}}$ \\
\hline 4 & $1.70^{\mathrm{a}}$ & $2.56^{\mathrm{a}}$ & $2.00^{\mathrm{a}}$ & $2.07^{\mathrm{a}}$ & $43^{b}$ & $141^{\mathrm{ab}}$ \\
\hline
\end{tabular}

1: See Materials and methods.

2: For treatments, see Table 5.

a, b, c: Within each column, means with the same superscript are not significantly different $(P<0.05)$. 
Reinfection. Unfortunately, there was no faecal sampling between days 11 and 20 after inoculation, but the pattern of oocyst shedding seemed to be very similar to that seen in Experiment 2. Thus, the faecal oocyst numbers declined during the 5 weeks of observation in all unchallenged groups, and in the challenged group 3B (LE-treated), whereas the oocyst numbers increased to a new peak on day 20 after challenge in the challenged groups $1 \mathrm{~B}$ and $2 \mathrm{~B}$. On day 20, the mean oocyst counts of the different groups were as follows: (1A) 74 600; (1B) 157 400; (2A) 38 700; (2B) 334 300; (3A) 68 500; (3B) 33 100. Among these, the oocyst count of group 2B was significantly higher than that of group 2A. Otherwise, there were no significant differences in oocyst number between the groups.

Some challenged lambs, mainly in groups $2 \mathrm{~A}$ and $3 \mathrm{~A}$, showed a softening of their faeces in the second week after challenge. Thus, on day 11 after challenge, one lamb in group 2B and 2 lambs in group 3B had diarrhoea.

All challenged groups showed a marked depression in weight gain during the second week after challenge. The peak intensity of the challenge infection seemed to occur between days 11 and 14 after inoculation. In this period the infected groups $1 \mathrm{~B}, 2 \mathrm{~B}$, and 3B had mean daily weight "gains" of -17 , -183 , and -133 grams, respectively, whereas the uninfected groups $1 \mathrm{~A}, 2 \mathrm{~A}$, and $3 \mathrm{~A}$ had daily weight gains of 275,167 , and 208 grams, respectively. Yet, there were no significant differences between challenged and unchallenged groups in this period due to large individual variations within each of the small groups. The challenged lambs were not able to fully compensate for the previous depression in weight gain during the last 3 weeks of observation.

\section{Discussion}

In the present investigation, treatment of young lambs with leucocyte extract (LE) from coccidia-immune donors consistently enhanced the severity of the ensuing first coccidial infection on pasture. Thus, there was a higher incidence of soft faeces (pastelike or diarrhoeic consistency), resulting in a higher mean faecal consistency score, and a more marked reduction in weight gain among the LE-treated lambs than among the untreated controls. Moreover, 5 LE-treated lambs died of coccidiosis during the 3 experiments, whereas only 2 control lambs died. These observations are difficult to interpret because very little is known about the composition and properties of the LE preparations used, and about the nature of the recipients' responses to the treatments.

The mean oocyst counts of the LE-treated groups were higher, although not significantly higher, than those of the untreated controls on most sampling days. It therefore seems reasonable to assume that the leucocyte extract used caused a suppression of the recipients' immune (and inflammatory) responses against the coccidia. This would allow the parasites to proliferate more extensively in the LE-treated lambs than in the controls, thereby causing a more extensive damage to the intestinal mucosa of the treated lambs. This, in turn, would lead to a higher incidence of diarrhoea and a more marked depression in weight gain among the LE-treated lambs. A similar clinical picture with increased oocyst output and reduced weight gains has been produced in partially immune lambs after immunosuppressive treatments with corticosteroids during coccidial infections (Chapman 1974). In the present experiments, most lambs were probably largely nonimmune to coccidia when turned 
out on pasture. If the LE preparations used really did induce a state of immunosuppression, it follows that the immune responses induced by the initial coccidial infection on pasture normally contribute to controlling the severity of that infection. Thus, it has been found that a primary Eimeria vermiformis infection in mice induces a host immune response which affects the course of that infection, apparently by reducing parasite reproduction (Rose et al. 1985).

An immunosuppressive effect of LE-treatments has not been observed in the investigations on Eimeria infections in other hosts (Liburd et al. 1972, Klesius et al. 1975, Klesius \& Kristensen 1977, Klesius et al. 1978, Klesius et al. 1979, Klesius \& Kirkpatrick 1983, Klesius \& Giambrone 1984), or in infections with various nematodes in sheep (Ross \& Halliday 1979a, Ross \& Halliday 1979b, Ross et al. 1979, Hunter et al. 1983, MacKenzie et al. 1982). In some of these investigations, however, LE from immune donors failed to transfer any protective immunity to the recipients (Klesius et al. 1975, Ross \& Halliday 1981, Hunter et al. 1983). Kirkpatrick \& Gallin (1975), on the other hand, reported that the cellular immune responses of a human patient became temporarily suppressed following treatments with leucocyte extract containing transfer factor. Likewise, Wilson et al. (1984) reported that dialyzable leucocyte extract from certain immune donors were able to suppress the cell-mediated immunity of the recipients.

The apparent immunosuppressive effects of the leucocyte extract used in the present investigation might have been either antigenspecific or nonspecific, or both. It has been found that dialysates of human leucocyte extract containing transfer factor have 2 opposing antigen-specific activities, which either augments (the inducer factor), or sup- presses (the suppressor factor) cell-mediated immunity (Lawrence \& Borkowsky 1983). Moreover, some of the other small molecules in crude leucocyte lysates may have a nonspecific suppressive effect on cell-mediated immunity. The variable effects of treatments with human leucocyte extract containing transfer factor are thought to be the result of variable proportions of inducer factor and suppressor factor in the preparations used. A similar explanation may also apply to ovine leucocyte extracts. If so, the preparations used in the present study may have contained a preponderance of suppressor activity (either specific or nonspecific).

An alternative explanation to the enhanced severity of clinical signs after LE-treatment is that this treatment induced a state of hypersensitivity with an accompanying severe inflammation of the intestinal mucosa resulting in diarrhoea. Thus, certain components of crude leucocyte lysates other than transfer factor may act nonspecifically to enhance the inflammatory response. However, it seems unlikely in light of the high oocyst counts of the LE-treated groups that a hyperimmune state had been induced and was the cause of the clinical signs.

Further experiments, using more refined techniques in the preparation of the leucocyte extract (e.g. dialysis to remove the small molecules with nonspecific effects on immune functions), as well as in the evaluation of the recipients' responses to the treatments, are necessary to reveal the mechanisms underlying the present findings. Only after further studies will it be possible to reach a valid conclusion as to the suitability of leucocyte extract in the prevention of coccidiosis in young lambs on pasture.

In this study, levamisole administered on 3 days around turnout had no beneficial effect. On the contrary, this treatment seemed to enhance the severity of the coccidial infect- 
ions, as evidenced by the occurrence of $3 \mathrm{fa}$ tal cases among the levamisole-treated lambs, whereas no controls died of coccidiosis in the same experiment. The surviving levamisole-treated lambs also had higher mean FCSs and a poorer weight gain than the controls during the acute phase of the infection, but these differences were not statistically significant. This result is in contrast to the findings of Giambrone \& Klesius (1985), who reported that chickens receiving levamisole had better weight gains for 3 weeks following coccidiosis vaccination (with live oocysts), and an improved resistance to challenge infections with Eimeria tenella when compared with untreated birds. However, in their study chickens were administered levamisole for the first time when only 4 days old, and vaccinated (infected) when 7 days old. The favourable effect of levamisole treatment in their study might therefore have been related to the young age of the chickens. Thus, Onaga et al. (1984) observed a beneficial effect of levamisole on the development of immunity to Eimeria tenella in 3-week-old chickens, but not in 6-week-old chickens.

The fact that the lambs treated with levamisole were more severely affected by the coccidia than the controls, suggests that levamisole either induced a suppression, or an excessive stimulation, of the lambs' immune and inflammatory responses against the coccidia. Further experiments are necessary to determine whether or not levamisole used at other dose levels or at other times relative to turnout will be able to reduce the severity of the first coccidial infection on pasture.

In the present study, sulphadimidine reduced the severity of the coccidial infections in most of the treated lambs. The lambs given sulphadimidine on average excreted fewer oocysts, had lower mean FCSs and better weight gains than the controls during the third and fourth week after turnout. However, several treated lambs showed a softening of their faeces or developed diarrhoea, and 2 of them died of coccidiosis. Thus, sulphadimidine did not have a fully satisfactory effect in the prevention of coccidiosis. These findings are in agreement with the results of similar experiments on the efficacy of sulphadimidine in controlling the severity of coccidiosis in lambs on pasture (Helle 1971, Helle 1981).

The challenge infections with 2 mill. oocysts about 6 weeks after turnout caused an increase in the oocyst counts of the previously untreated or sulphadimidine-treated lambs, but not in those of the LE-treated lambs. Several challenged lambs showed a softening of their faeces between days 10 and 17 after inoculation. From about day 10 after challenge the inoculated lambs also showed a marked depression in weight gain, which lasted about one week. These findings showed that the lambs were only partially immune to a heavy challenge infection with coccidia after the initial infection on pasture. However, the immunity acquired after the initial infection was apparently sufficient to protect the lambs from the natural reinfections on pasture, as none of the lambs exposed only to the natural reinfection showed any clinical signs of coccidiosis.

The previously sulphadimidine- or LEtreated lambs showed a somewhat greater reduction in weight gain during the acute phase of the challenge infection than did the previously untreated lambs. This finding suggests that the LE- and sulphadimidinetreated lambs were slightly more susceptible (less immune) to the reinfection than the untreated lambs. However, when the FCSs and the weight gains are also taken into consideration, there were no obvious differences between the different challenged groups in their susceptibility to the challenge infections. 


\section{Acknowledgements}

The authors thank L. Hjerpeton and B. A. Øyen for technical assistance at the Division of Parasitology. Further, we wish to thank Dr. H. J. Larsen at the Department of Microbiology and Immunology for his advice and cooperation during this study, and the technical staff at the same department for their assistance in the preparation of the cell extracts. This investigation was supported by a grant from the Norwegian Agricultural Research Council (NLVF).

\section{References}

Brunner CJ, Muscoplat CC: Immunomodulatory effects of levamisole. J. Amer. vet. med. Assoc. 1980, 176, 1159-1162.

Chapman HD: The immunity of lambs to coccidia acquired in the field and by artificial infection. Res. Vet. Sci. 1974, 16, 7-11.

Giambrone JJ, Klesius PH: Effect of levamisole on the response of broilers to coccidiosis vaccination. Poultry Sci. 1985, 64, 1083-1089.

Gjerde $B$, Helle $O$ : Efficacy of toltrazuril in the prevention of coccidiosis in naturally infected lambs on pasture. Acta vet. scand. 1986, 27, 124-137.

Helle $O$ : Winter resistant oocysts in the pasture as a source of coccidial infection in lambs. Acta vet. scand. 1970, 11, 545-564.

Helle $O$ : Gastrointestinal parasites in sheep on lowland pastures in eastern Norway. Acta vet. scand. 1971, Suppl. 34, 118 pp.

Helle $O$ : Behandling av lam mot coccidiose. (Anticoccidial treatment of lambs). Norsk Vet.-tidsskr. 1981, 93, 351-352.

Helle $O$, Hilali $M$ : Differentiation of Eimeria species infecting sheep during the grazing season on permanent and new pastures under Norwegian conditions. Acta vet. scand. 1973, 14, 57-68.

Hunter AR, MacKenzie G, Ross JG: A comparison of the effects of dialysed and non-dialysed transfer factor preparations on Haemonchus contortus infections in young lambs. Vet. Res. Commun. 1983, 6, 227-234.

Kirkpatrick CH, Gallin JI: Suppression of cellular immune responses following transfer factor: Report of a case. Cell. Immunol. 1975, $15,470-474$.

Klesius, PH, Elston AL, Chambers WH, Fudenberg $\mathrm{HH}$ : Resistance to coccidiosis (Eimeria ferrisis) in C57BL/6 mice: Effects of immunization and transfer factor. Clin. Immun. Immunopathol. 1979, 12, 143-149.

Klesius PH, Fudenberg HH, Smith CL: Comparative studies on dialyzable leukocyte extracts containing transfer factor - a review. Comp. Immunol. Microbiol. infect. Dis. 1980, 3, 247-260.

Klesius, PH, Giambrone JJ: Adoptive transfer of delayed hypersensitivity and protective immunity to Eimeria tenella with chicken-derived transfer factor. Poultry Sci. 1984, 83, 1333-1337.

Klesius PH, Kirkpatrick CH: Dialyzable leukocyte extract containing transfer factor - its future in veterinary medicine. In: Immunobiology of Transfer Factor. Kirkpatrick CD, Burger DR, Lawrence S (eds.). Academic Press, New York 1983, p. 129-140.

Klesius PH, Kramer T, Burger D, Malley A: Passive transfer of coccidian oocyst antigen and diphtheria toxoid hypersensitivity in calves across species barriers. Transplant. Proc. 1975, 7, 449-452.

Klesius PH, Kristensen $F$ : Bovine transfer factor: Effect on bovine and rabbit coccidiosis. Clin. Immun. Immunopathol. 1977, 7, 240252.

Klesius PH, Qualls DF, Elston AL, Fudenberg $H H$ : Effects of bovine transfer factor (TFd) in mouse coccidiosis (Eimeria ferrisi). Clin. Immun. Immunopathol. 1978, 10, 214-221.

Lawrence HS: The transfer in humans of delayed skin sensitivity to streptococcal M substance and to tuberculin with disrupted leucocytes. J. clin. Invest. 1955, 34, 219-230.

Lawrence HS, Borkowsky W: A new basis for the immunoregulatory activities of transfer factor - an arcane dialect in the language of cells. Cell. Immunol. 1983, 82, 102-116.

Liburd EM, Pabst HF, Armstrong WD: Transfer factor in rat coccidiosis. Cell. Immunol. $1972,5,487-489$.

MacKenzie G, Hunter AR, Ross JG: The effects 
of treatment with transfer factor, parasitic antigen and precipitated immunoglobulin on the parasitological and histopathological responses in Haemonchus contortus infection in lambs under six months of age. J. Helminthol. 1982, 56, 305-313.

Onaga $H$, Tajuma $M$, Ishii $T$ : Effect of levamisole on the immune response of chickens to infections with Eimeria tenella. Zbl. Bakt. Mikrobiol. Hyg., Ser. A, 1984, 256, 323-327.

Rose ME: Host immune responses. In: Long, P. L. (ed.). The Biology of the Coccidia. University Park Press, Baltimore 1982, pp. 329-371.

Rose ME, Wakelin D, Hesketh P: Susceptibility to coccidiosis: contrasting course of primary infections with Eimeria vermiformis in $\mathrm{BALB} / \mathrm{c}$ and $\mathrm{C} 57 / \mathrm{BL} / 6$ mice is based on immune responses. Parasit. Immunol. 1985, 7, 557-566.

Ross JG, Duncan JL, Halliday WG: Investigation of Haemonchus contortus infections in sheep. Comparison of irradiated larvae and transfer factor treatment. Res. Vet. Sci. 1979, 27, 258-259.

Ross $J G$, Halliday $W G$ : Investigations of 'transfer factor' activity in the transfer of immunity to Trichostrongylus axei infections in sheep. Res. Vet. Sci. 1979a, 26, 41-46.

Ross JG, Halliday $W G$ : Investigations of 'transfer factor' activity in immunity to Ostertagia circumcincta and Trichostrongylus colubriformis infections in sheep. Int. J. Parasitol. 1979b, 9, 281-284.

Ross JG, Halliday WG: Passive transfer of immunity to Tristrongyle species infections in sheep. Investigations of specificity and limitations of 'transfer factor' activity with Trichostrongylus axei infections. Vet. Res. Commun. 1981, 4, 287-290.

Wilson GB, Fudenberg HH, Keller RH: Guidelines for immunotherapy of antigen-specific defects with transfer factor. J. clin. lab. Immunol. 1984, 13, 51-58.

\author{
Samandrag \\ Effekten av leukocyttekstrakt, levamisol og sulfa \\ dimidin på naturlege koksidieinfeksjonar hos \\ unge lam.
}

I tre forsøk vart leukocyttekstrakt (LE), framstilt frå søyer immune mot koksidiar, gitt til lam like før dei vart sleppte ut på koksidieinfisert beite for å prøva og gjera dei meir resistente mot koksidieinfeksjonar. LE vart gitt anten i.v. eller i.p. til lamma 7, 5 eller 2 dagar før beiteslepp. I alla forsøka synte lamma som fekk LE alvorlegare symptom på koksidiose enn dei ubehandla kontrollane. Samanlikna med dei sistnemnde, hadde dei LE-behandla lamma ein høgare diaréfrekvens, høgare mortalitet, dårlegare tilvekst i 3. og 4 . beiteveke, og høgare oocystetal i feces på dei fleste prøvedatoane. Ein reknar det difor som sannsynleg at LE har hatt ein immunosuppressiv effekt på lamma. Behandling med sulfadimidin i ein dose på $200 \mathrm{mg} / \mathrm{kg}$ på dag 12,13 og 14 etter beiteslepp greidde delvis å førebyggja koksidiose, men nokre lam fekk diaré, og nokre få daua. Dei lamma som fekk sulfadimidin hadde likevel i gjennomsnitt ein betre tilvekst enn kontrollane i $3 . \operatorname{og} 4$. beiteveke. Tre dosar av levamisol, kvar på $2 \mathrm{mg} / \mathrm{kg}$, gitt annankvar dag frå dag 2 før beiteslepp, syntest å gjera lamma meir mottakelege for den fyrste koksidieinfeksjonen på beite. Forsøk med kunstig reinfeksjon av lamma med 2 mill. oocyster 6 veker etter beiteslepp synte at dei lamma som tidlegare hadde fătt sulfadimidin eller LE, hadde utvikla ein om lag like sterk immunitet mot koksidiar som dei tidlegare ubehandla lamma. Alle lamma var likevel på dette tidspunktet berre delvis immune mot koksidieinfeksjonar, og synte moderate kliniske symptom etter den kunstige reinfeksjonen. Denne immuniteten var likevel sterk nok til å hindra at den naturlege reinfeksjonen på beite resulterte i klinisk koksidiose.

\section{(Received November 3, 1986).}

Reprints may be requested from: B. Gjerde, Division of Parasitology, Department of Internal Medicine I, Norwegian College of Veterinary Medicine, P. O. Box 8146 Dep., N-0033 Oslo 1, Norway. 